\title{
Science Graduate Employability and English Language Proficiency: Findings from a Malaysian Public University
}

\author{
Wendy Hiew, Rose Patsy Tibok, Wirawati Ngui, \\ Darmesah Gabda and Qhatrunnada Suyansah \\ Universiti Malaysia Sabah, Kota Kinabalu, Sabah, Malaysia \\ https://orcid.org/0000-0001-5245-4942 \\ https://orcid.org/0000-0001-5173-1629 \\ https://orcid.org/0000-0003-0204-6523 \\ https://orcid.org/0000-0002-1703-1626 \\ https://orcid.org/0000-0002-4579-3206
}

\begin{abstract}
This study investigated the relationship between the employability of science graduates of a public university in Malaysia and their English language proficiency. Utilising a quantitative research design, the study involved 3,918 graduates from the 2015, 2016 and 2017 graduating years. Using available secondary data, three variables were examined: the graduates' employment status, their English Language course results, and their Malaysian University Entrance Test (MUET) results. The data was analysed using descriptive statistics, KolmogorovSmirnov test and Chi-square test. Findings showed the number of unemployed graduates was consistently greater than employed graduates although the unemployment percentage decreased progressively each year. No conclusive evidence however could be ascertained to suggest English Language proficiency as the main determinant affecting employability since the highest number of employed and unemployed graduates were from the Intermediate and Upper Intermediate language proficiency range. This points to other factors impacting employability which higher learning institutions may need to address in order to add value to their graduates' future work credentials.
\end{abstract}

Keywords: employment; English language proficiency; graduate employability; science graduates; transversal skills

\section{Introduction}

Every year, universities worldwide produce graduates from various disciplines of study focused on the common aim of securing jobs in their fields of specialisation. The requirements for employment have however expanded from being solely expertise dependent; while subject-specific knowledge and skills are 
still pertinent, current era employers now seek well-rounded candidates with additional attributes that would benefit the workplace. These attributes typically include positive work ethics and abilities that help graduates thrive in their work environment for the benefit of the organisation and the labour force. In addition, employers require graduates who are adaptable and capable of meeting the changing demands of the industry. Since graduates enter the labour force supposedly ready and well-equipped to respond to the demands of the economy, the responsibility for ensuring that these individuals are holistic and with marketdriven attributes is placed on higher learning institutions as the training ground for knowledge, skills and competency.

Graduate employability is likewise a concern in Malaysia. In 2019, close to $60 \%$ of fresh graduates (first degree and above) failed to gain employment within a year of graduation (D'Silva, 2020). An annual report published by Bank Negara Malaysia revealed a considerable mismatch between supply and demand as the number of diploma and degree holders had increased annually from 2010 to 2017 with the figure surpassing the number of high-skilled workers that were being employed (Murugasu, Hakim \& Yau, 2019). The report highlighted the need to create more high-skilled work positions as a means of addressing or mitigating this imbalance between supply and demand. The report also reiterated the need for universities to produce graduates who were well-trained in their specific disciplines and possessed supplementary attributes that would drive their career performance.

In the attempt to determine the drivers for graduate employability in Malaysia, researchers have suggested various angles of investigation including applying a graduate employability model for assessing graduates' readiness based on their generic skills (Singh, Thambusamy \& Ramly, 2014), comparing the perception of employers and employees (Alias, Hamzah \& Yahya, 2013), and determining graduates' level of employability (Ahmad, Kenayathulla \& Idris, 2017). Yet the actual factors that impact graduate employability have remained unanswered.

\subsection{Research Rationale and Questions}

The responsibility placed on higher education systems in relation to the employability of graduates is a global phenomenon (Yorke, 2006). In Malaysia, higher education institutions (HEIs) are tasked with a similar obligation to "improve employability aspects among our graduates" (Ministry of Higher Education, 2007, p.11). In the National Higher Education Action Plan (2007-2010), graduate unemployment was partly attributed to "the lack of appreciation of the different roles that education and training play in employment" (Ministry of Higher Education, 2007, p.42). Renewed measures referred to as shifts were introduced in the Malaysia Education Blueprint (MBE) with the development of quality graduates placed as the first shift (Ministry of Education, 2015). In accordance to this, HEIs were expected to improve their existing curriculums and systems by collaborating with industry, promoting entrepreneurial opportunities for students and staff, and producing graduates who embody the desired attributes. These attributes, as specified in the MBE, were categorised as knowledge and skills (knowledge, thinking skills, and language proficiency) as 
well as ethics and morality (patriotism, leadership skills, ethics and spirituality). Among the myriad of factors, English language proficiency was suggested as a major contributing aspect to graduate employability in Malaysia. Malaysian researchers sought the viewpoints of employers and concluded that the ability to converse in English and to use the language in written form were perceived as the two most important graduate skills (Hamid, Islam, \& Abd Manaf, 2014) with employers preferring candidates who demonstrated better language accuracy (Zainuddin, Pillai, Dumanig \& Phillip, 2019).

Based on this, this study therefore sought to ascertain whether there was indeed any significant relationship between the employability of science graduates and their English language proficiency within the context of a public university in Sabah, Malaysia. The research questions were:

(i) Is there a significant relationship between the employability of the university's science graduates and their Malaysian University English Test (MUET) results?

(ii) Is there a significant relationship between the employability of the university's science graduates and their university English Language course results?

\section{Literature Review}

Employability is defined as "a set of achievements - skills, understandings and personal attributes - that makes graduates more likely to gain employment and be successful in their chosen occupations, which benefits themselves, the workforce, the community and the economy" (Yorke, 2006, p.8). This definition implies that employability consists a complex set of attributes rather than any singular reason. Various research examining employability factors have further categorised these into hard and soft skills. Hard skills, also known as technical skills, refer to specialised information and abilities that are discipline-related (Turner, 2004). Soft skills or generic skills on the other hand are those required to perform optimally in professional and social contexts. These skills may include language proficiency, communicative ability, personal qualities, critical literacy and critical thinking skills (Koo, 2007). In discussing the contribution of higher education to the labour market, Yorke (2006) noted that the development of generic skills such as communicating, collaborating and the managing of time were perceived as below par.

A research by Ilhaamie, Rosmawani and Yusmini (2018) explored graduate employability through students' ranking of the skills that contributed to employability. The study involved 300 respondents from three private and three public universities. The respondents indicated that being disciplined was the most important employability skill, followed by being responsible, and demonstrating positivity. A comparison between the private and public universities also revealed different perceptions of skills that contributed to employability. For example, more respondents from public universities considered the skills of communication, organisation, problem solving, decision making, creative and innovative thinking, and leadership as important. On the other hand, students from private universities were more prone to regard fluency in the English language, fluency in a third language, and analytical skills as important. As such, it could be inferred that public and private universities differ in their curriculum 
content emphasis. Another comparative study which attempted to ascertain the level of generic skills practised by economic students in a Malaysian university and an Indonesian university (Hadiyanto \& Ibrahim, 2013) revealed that the Indonesian students rated their generic skills higher than their Malaysian counterparts.

Researchers have also identified the attributes that employers generally seek in graduates. In terms of employability attributes, emphasis is placed on the ability to communicate (Hanapi \& Nordin, 2014; Omar et al., 2012; Rasul et al., 2013). This implies that candidates are expected to be able to interact well within the organisation and when dealing with clients (Omar et al., 2012). Apart from verbal communication, employers also seek graduates with the ability to listen and interpret information as well as convey written information effectively (Rasul et al., 2013). In Hanapi and Nordin's study (2014), communication was associated with fluency in the English language. English language proficiency was also highlighted as a primary employability factor with employers preferring candidates who demonstrated better language accuracy (Zainuddin, Pillai, Dumanig \& Phillip, 2019). The importance of the English language for employability was further revealed in a study whereby employers ranked the ability to converse in English and the ability to use English in written form as the two most desired skills (Hamid, Islam \& Abd Manaf, 2014). Other than the Malay language, fluency in English and Chinese provided an advantage to job candidates as it was a common requirement in electronic advertisements (Omar et al., 2012). Another significant employability attribute was teamwork as employers valued candidates who could collaborate with colleagues (Omar et al., 2012). This also meant being able to share information and resources with team members and getting along with others despite cultural and background differences (Rasul et al., 2013). In addition, problem solving was noted as an important skill which required employees to be creative (Hanapi \& Nordin, 2014) and contribute ideas and solutions (Rasul et al., 2013). Employers also wanted employees with positive personal qualities with many of these related to work ethics such as honesty, responsibility, discipline and commitment (Omar et al., 2012; Rasul et al., 2013).

Apart from employability attributes, technology literacy and technical skills were viewed as added values. Technology skills include the ability to use computer programmes as well as operate tools and machines (Rasul et al., 2013). Basic computer knowledge typically includes the use of Microsoft applications although certain positions such as engineers and programme analysts require candidates to demonstrate technical skills in more advanced software and systems (Omar et al., 2012). However, despite the importance of technical skills, a study involving lecturers and employers revealed that graduates lacked these (Hanapi \& Nordin, 2014). In a study conducted by Lee, Ling, Lim and Cham (2019), fresh graduates similarly affirmed that they were ill-equipped with technology and technical skills upon working. The study explored the challenges of 18 accounting graduates who had graduated and secured employment in accounting-related departments within three years of graduation. The respondents expressed a lack of accounting knowledge and skills more 
specifically in matters related to audit, taxation and analysis of financial data. The respondents subsequently indicated that their education had not fully prepared them with the essential knowledge and skills to perform optimally at work. The revelation that fresh graduates felt ill-equipped at work is a significant indication of a gap between higher education and industry. Studies involving undergraduate students have also highlighted a lack of confidence among respondents in relation to hard skills. A study that investigated 425 final year undergraduate students' self-perceived employability level revealed that the respondents ranked their academic attributes at fourth place behind teamwork, work and career resilience, and conscientiousness (Wong, Samsilah, Siaw, Tajularipin \& Habibah, 2018). The findings indicated that although the students perceived themselves as possessing certain soft skills that were essential for employability, they appeared to be less confident about hard skills related to academic performance. A similar predicament was observed in a study of 171 final year engineering students at Universiti Malaysia Perlis (Yusof \& Jamaluddin, 2015) whereby it was found that although a majority of the students $(90.6 \%)$ identified enhancing employability skills as one of the proactive measures they had taken to secure employment, more than half $(57.9 \%)$ indicated that they were insecure about their academic performance while almost half (49.1\%) expressed a perceived personal lack of technical skills.

\section{Methodology}

\subsection{Research Design}

This study employed a quantitative research design employing analysis of available secondary data. The samples consisted of 3,918 science graduates from the graduating years 2015, 2016 and 2017 of five science-based faculties of a public university in Sabah namely the Faculty of Science and Natural Resources, Faculty of Food Science and Nutrition, Faculty of Sustainable Agriculture, Faculty of Engineering and Faculty of Computing and Informatics. Three variables were examined: the graduates' employment status in relation to their parent faculties, their English language proficiency course results or English language advanced course results undertaken at the university, and their Malaysian University Entrance Test (MUET) results.

\subsection{Data Source and Collection}

The data used for the analytical purpose in this study was secondary data extracted from the graduates' university English Language course results, their MUET results, and the Graduate Tracer Study sourced from the university's Career \& Alumni Centre. Started in 2002, the Ministry of Higher Education conducts annual collection of graduate data by means of this Graduate Tracer Study. For this study, we included all the respondents from the 2015, 2016, and 2017 graduating years who had submitted their Graduate Tracer Study forms. The variables for this study were the graduates' employability status, English results, and soft skills. However, the amount of information that this study had access to in the Graduate Tracer Study was limited since most of the data fell under the purview of Act 709 of the Malaysian Personal Data Protection Act 2010. Information access was limited to numbers and percentages related to graduate employability according to faculty and programme of study. More specific 
information such as employment by gender, job type, work location and salary were not made available.

\subsection{Data Analysis}

The data that could be obtained was tabulated and descriptive analysis utilised to analyse the total number of employed and unemployed graduates. The normal distribution for the graduates' university English Language course results and the MUET results was determined using the Kolmogorov-Smirnov normality test; this allowed for the comparison of the sample scores to a normally distributed set of scores with the same mean and standard deviation with the null hypothesis being that the said sample distribution is normal (Ghasemi \& Zahediasl, 2012).

When the test outcomes indicated the data was not normally distributed, the independent Chi-square test (a non-parametric test) was adopted to determine the relationship between the employability of the university's science graduates and their undergraduate English Language course results and MUET results, respectively. This usage of the Chi Square test for the purpose of ascertaining whether two categorical variables have a relationship (Field, 2009). The Chi Square test for independence of two variables, a cross classification table-based test, evaluates the nature of the relationship between these variables. The alternative hypothesis is that there is a relationship between the variables. (Wuensch, 2011). The test statistics of Chi Square of independence is as follows (Yahya et. al, 2008):

$$
\chi^{2}=\frac{\left(o_{i j}-\epsilon_{i j}\right)^{2}}{\epsilon_{i j}}
$$

where $o_{i j}$ is the observed count and $\epsilon_{i j}$ is the expected count for contingency table with $i^{\text {th }}$ row, $i=1,2, . ., \mathrm{r}$ and $j^{\text {th }}$ column, $j=1,2, . ., \mathrm{c}$.

\section{Findings}

4.1 Number of graduates based on faculties for the period 2015-2017

The number of students who graduated from the various science-based faculties in the university from 2015, 2016 and 2017 was as follows (Table 1):

Table 1: Number of science-based graduates in 2015, 2016 \& 2017

\begin{tabular}{lccc}
\hline Faculty & $\begin{array}{c}2015 \\
(\%)\end{array}$ & $\begin{array}{c}2016 \\
(\%)\end{array}$ & $\begin{array}{c}2017 \\
(\%)\end{array}$ \\
\hline FSSA & 52.5 & 53.2 & 47.2 \\
\hline FSMP & 16.2 & 12.0 & 12.7 \\
\hline FPL & 5.5 & 6.1 & 7.7 \\
\hline FKJ & 18.5 & 15.0 & 16.0 \\
\hline FKI & 7.3 & 13.7 & 16.4 \\
\hline${ }^{*}$ FSSA: Faculty of Science and Natural Resources & FSMP: Faculty of Food Science and Nutrition \\
FPL: Faculty of Sustainable Agriculture & FKJ: Faculty of Engineering & FKI: Faculty of Computing $\mathcal{E}$ \\
Informatics & & &
\end{tabular}

The majority of graduates according to faculty were from the Faculty of Science and Natural Resources (FSSA) with $52.5 \%$ of the overall total in 2015, 53.2\% in 2016, and $47.2 \%$ in 2017. A gradual increase of graduates over the three-year period was also observed in the Faculty of Sustainable Agriculture (FPL) with 
$5.5 \%$ graduates in the overall total in $2015,6.1 \%$ in 2016 and $7.7 \%$ in 2017 . A similar increase was also posted in the Faculty of Computing and Informatics (FKI) with $7.3 \%$ in $2015,13.7 \%$ in 2016 and $16.4 \%$ in 2017.

The Faculty of Food Science and Nutrition (FSMP) posted a decrease in graduates in 2016 with $12 \%$ compared to $16.2 \%$ in 2015 and $12.7 \%$ in 2017 . The Faculty of Engineering (FKJ) showed a slight drop in graduates completing their programme in 2016 with $15 \%$ against $18.5 \%$ in 2015 and $16 \%$ in 2017. Although the number of students graduating from the Faculty of Sustainable Agriculture (FPL) remained consistently the lowest among the five science-based faculties with 5.5\% graduates in 2015, 6.1\% in 2016 and $7.7 \%$ in 2017, these figures were actually a consistent increase in terms of the number of students successfully completing their studies from the faculty.

\subsection{Graduate Employment Status}

In terms of employment, data was classified under four broad categories by the university's Alumni Centre: Employed, Unemployed, Others and No Information. However, unlike the 2015 and 2016 data for the "Others" category, the 2017 data was further segregated into three streams: those who were (i) pursuing further studies or qualifications, (ii) improving skills, and (iii) in job transition or waiting for work placements.

\section{Employment status for 2015}

The 2015 graduate count according to faculty was, in descending order, FSSA with 569, FKJ 201, FSMP 176, FKI 78 and FPL 60. From this overall graduate total of $1,084,38.2 \%$ had secured employment while 53\% remained unemployed, $7.7 \%$ classified in "Others", and the status of $1.1 \%$ could not be determined (Table 2).

Table 2: Employment status of science-based graduates in 2015

\begin{tabular}{r|cccccc}
\hline & FKI & FKJ & FPL & FSMP & FSSA & Overall Total \\
\hline Employed & $47.4 \%$ & $42.8 \%$ & $25.0 \%$ & $56.3 \%$ & $31.1 \%$ & $38.2 \%$ \\
\hline Unemployed & $48.7 \%$ & $46.7 \%$ & $65.0 \%$ & $36.9 \%$ & $59.6 \%$ & $53.0 \%$ \\
\hline Others & $3.9 \%$ & $8.9 \%$ & $8.3 \%$ & $5.7 \%$ & $8.2 \%$ & $7.7 \%$ \\
\hline No Information & $0 \%$ & $1.5 \%$ & $1.7 \%$ & $1.1 \%$ & $1.1 \%$ & $1.1 \%$ \\
\hline
\end{tabular}

Among the five faculties, graduates from FSMP had the highest percentage of graduates being employed with $56.3 \%$ in job placements. This was followed by FKI with $47.4 \%$, FKJ with $42.8 \%$, FSSA with $31.1 \%$ and FPL with $25 \%$. From Table 2 , it is evident that the number of unemployed science-based graduates produced by the university at $53 \%$ was greater than the three other classifications ("Employed", "Others" and "No Information") with a combined total of $47 \%$. Unemployment was highest among graduates from FPL with $65 \%$ not working. This was then followed at $59.6 \%$ by FSSA, $48.7 \%$ by FKI, $46.7 \%$ by FKJ, and $36.9 \%$ by FSMP.

\section{Employment status for 2016}

From the overall number of 1,305 students graduating from the university in 2016, $44 \%$ found employment while $47.9 \%$ were still unemployed (Table 3 ). 
Table 3: Employment status of science-based graduates in 2016

\begin{tabular}{r|cccccc}
\hline & FKI & FKJ & FPL & FSMP & FSSA & Overall Total \\
\hline Employed & $49.7 \%$ & $55.6 \%$ & $42.5 \%$ & $61.8 \%$ & $35.4 \%$ & $44.0 \%$ \\
\hline Unemployed & $40.2 \%$ & $39.3 \%$ & $53.8 \%$ & $28.7 \%$ & $56.0 \%$ & $47.9 \%$ \\
\hline Others & $10.1 \%$ & $5.1 \%$ & $3.7 \%$ & $8.9 \%$ & $8.2 \%$ & $7.8 \%$ \\
\hline No Information & $0 \%$ & $0 \%$ & $0 \%$ & $0.6 \%$ & $0.4 \%$ & $0.3 \%$ \\
\hline
\end{tabular}

A total of $7.8 \%$ were categorised under "Others" while $0.3 \%$ did not provide any information. As in 2015, graduates from FSMP were found to be the most employable among the five science-based faculties in 2016 with $61.8 \%$ holding jobs. This was followed by FKJ with $55.6 \%$ of their graduates in employment, FKI with $49.7 \%$ and FPL with $42.5 \%$. FSSA posted the lowest active employment rate with only $35.4 \%$ of its graduates able to secure job placements.

\section{Employment status for 2017}

In 2017, the total number of students who graduated from the five science-based faculties in the university was 1,538. From this figure, $37.2 \%$ managed to secure employment (Table 4).

Table 4: Employment status of science-based graduates in 2017

\begin{tabular}{r|cccccc}
\hline & FKI & FKJ & FPL & FSMP & FSSA & Overall Total \\
\hline Employed & $50.8 \%$ & $43.1 \%$ & $27.1 \%$ & $59.2 \%$ & $26.2 \%$ & $37.2 \%$ \\
\hline Unemployed & $28.1 \%$ & $46.3 \%$ & $50.8 \%$ & $30.6 \% \%$ & $57.2 \%$ & $46.8 \%$ \\
\hline Further Study & $3.2 \%$ & $1.6 \%$ & $10.2 \%$ & $1.0 \%$ & $7.7 \%$ & $5.3 \%$ \\
\hline Improving Skills & $3.6 \%$ & $3.7 \%$ & $0 \%$ & $2.0 \%$ & $1.2 \%$ & $2.0 \%$ \\
\hline $\begin{array}{r}\text { Waiting for job } \\
\text { placements }\end{array}$ & $4.4 \%$ & $2.0 \%$ & $5.1 \%$ & $4.6 \%$ & $5.6 \%$ & $4.7 \%$ \\
\hline No Information & $9.9 \%$ & $3.3 \%$ & $6.8 \%$ & $2.6 \%$ & $2.1 \%$ & $4.0 \%$ \\
\hline
\end{tabular}

The remaining $62.8 \%$ were divided into the following classifications: $46.8 \%$ without employment, $5.3 \%$ pursuing further studies or qualifications, $2 \%$ engaged in skills improvement initiatives, and $4.7 \%$ waiting for job placements. No information could be obtained or was provided by the final $4 \%$ ) graduates of the class of 2016.

Although the graduates classified under "Further Study", "Improving Skills" and "Waiting for Job Placement" were technically not working, they were excluded from the "Unemployed" classification since their situations were deemed as temporary with them expected to secure jobs once their studies, training or 'transit' work period was completed.

\section{Overall Employment Overview}

The number of unemployed graduates was in overall greater than employed graduates in 2015, 2016 and 2017 (Table 5). 
Table 5: Summary of employment status for 2015, 2016 and 2017

\begin{tabular}{lccc}
\hline Category/Year & $\begin{array}{c}\mathbf{2 0 1 5} \\
\mathbf{( \% )}\end{array}$ & $\begin{array}{c}\mathbf{2 0 1 6} \\
\mathbf{( \% )}\end{array}$ & $\begin{array}{c}\mathbf{2 0 1 7} \\
\mathbf{( \% )}\end{array}$ \\
\hline Employed & 38.2 & 44.0 & 37.2 \\
\hline Unemployed & 53.0 & 47.9 & 46.8 \\
\hline Others & 7.7 & 7.8 & \\
\hline Further study & & & 5.3 \\
\hline Improving skills & & & 2.0 \\
\hline Waiting for job placement & & 0.3 & 4.7 \\
\hline No information & 1.1 & & 4.0 \\
\hline
\end{tabular}

It is notable that the unemployment percentage decreased progressively during the 2015-2017 period with 53\% in 2015, 47.9\% in 2016 (a reduction of 5.1\% from the previous year), and $46.8 \%$ in 2017 (1.1\% reduction from 2016). The rate of employment however was not as consistent in this three-year period: although 2016 posted an increase of $5.8 \%$ in the number of graduates in employment compared to 2015, this figure was reversed in 2017 when the percentage of employed graduates dropped to $37.2 \%$ from the previous year's total of $44 \%$, a decrease of $6.8 \%$.

\subsection{Employment Status and English Language Course Results Undertaken at University}

Students from the various faculties in the university are required to enrol in English Language learning courses in their first and second year of study. These courses, staggered over four semesters, are aimed at (1) improving English Language skills among low proficiency learners, and (2) enhancing usage and fluency in more advanced level students. The MUET results of learners upon registration in their respective university programmes determine whether they are enrolled into proficiency level classes or advanced level sessions. As of 2020, students with MUET results of Band 3 and below would be required to join the proficiency level whereas those with Band 4 and above are registered into advanced level classes.

In this study, it was notable that the highest percentage of employed graduates in 2015, 2016 and 2017 were those who had obtained the B+ grade in their university English Language course results (Table 6). This grade is awarded for marks obtained between the 70-74 range out of a possible 100. However, the highest percentage of unemployed graduates in 2015 and 2017 also scored B+. For 2016, the highest percentage of unemployed graduates had obtained B grade in their university English Language courses.

Table 6: University English Language course results of 2015, 2016 and 2017 graduates of science-based faculties

\begin{tabular}{c|cc|cc|cc}
\hline \multirow{2}{*}{$\begin{array}{c}\text { University } \\
\text { Grade }\end{array}$} & \multicolumn{2}{|c|}{2015 (\%) } & \multicolumn{2}{c|}{ 2016 (\%) } & \multicolumn{2}{c}{2017 (\%) } \\
\cline { 2 - 7 } & Employ. & UnEmploy. & Employ. & UnEmploy. & Employ. & UnEmploy. \\
\hline A & 7.1 & 5.4 & 3.0 & 2.5 & 3.3 & 2.4 \\
\hline A- & 8.9 & 8.0 & 7.8 & 7.4 & 7.2 & 6.6 \\
\hline B+ & 13.9 & 15.1 & 16.2 & 13.0 & 15.7 & 15.7 \\
\hline B & 9.4 & 15.6 & 14.1 & 13.7 & 14.1 & 15.7 \\
\hline
\end{tabular}




\begin{tabular}{c|cc|cc|cc}
\hline B- & 5.3 & 7.2 & 7.4 & 7.7 & 6.4 & 7.9 \\
\hline C+ & 0.9 & 2.3 & 2.5 & 3.0 & 1.6 & 2.1 \\
\hline C & 0.4 & 0.5 & 0.7 & 0.8 & 0.4 & 0.6 \\
\hline C- & 0.0 & 0.1 & 0.2 & 0.2 & 0.1 & 0.1 \\
\hline D & 0.1 & 0.0 & 0.0 & 0.0 & 0.0 & 0.0 \\
\hline
\end{tabular}

Employability and University English Language results in 2015

In 2015, graduates with B+ grade results accounted for $13.9 \%$ of the overall total of those with job placements (Table 6). For summation purposes, graduates with A range grades (A and $\mathrm{A}-$ ) posted a combined $16 \%$ employment rate while those in the $\mathrm{B}$ range $(\mathrm{B}+, \mathrm{B}$ and $\mathrm{B}-)$ reported a $28.6 \%$ employed percentage. $1.3 \%$ of graduates with low results in the $\mathrm{C}$ range $(\mathrm{C}+, \mathrm{C}$ and $\mathrm{C}-)$ had secured jobs. Graduates who had failed their university English Language course had a $0.1 \%$ employment rate. As reflected in Table 6, the majority of employed graduates in 2015 were those with B+ English Language attainment. However, the highest percentage of unemployment among science-based faculties in the university in 2015 were also from the B grade range with $15.6 \%$ with $B$ and $15.1 \%$ with $B+$ achievements. Low range English Language results (C+, C, C and D) contributed a combined 2.9\% towards the unemployability results of 2015 graduates. Graduates with A grade (5.4\%) and A- grade (8\%) were among those without jobs.

\section{Employability and University English Language results in 2016}

For $2016,16.2 \%, 14.1 \%$ and $7.4 \%$ of the employed graduates had obtained B+, B and B- grades respectively in their English Language courses in the university. The combined total of this grade range, $37.7 \%$, reflected the highest number of employed graduates for 2016. Low proficiency graduates (C+, C, and C-) made up the rest of the employed graduate count with $3.4 \%$ (Table 6 ).

This pattern was repeated for the "Unemployed" category whereby the bulk of graduates without job placements had obtained English Language course marks in the $\mathrm{B}+$ and $\mathrm{B}$ range with $13 \%$ having $\mathrm{B}+$ results and $13.7 \%$ with $\mathrm{B}$ grade. $7.7 \%$ of the overall total of unemployed 2016 graduates had B- results. $4 \%$ of the jobless graduate total had low proficiency English Language grades ( $\mathrm{C}+, \mathrm{C}$ and $\mathrm{C}-$-). 9.9\% of the jobless graduate figure were those who had obtained A and A- in their English Language courses.

\section{Employability and University English Language results in 2017}

Employability in 2017 was highest among graduates with English Language results of $\mathrm{B}+(15.7 \%), \mathrm{B}(14.1 \%)$ and $\mathrm{B}-(6.4 \%)$ while $10.5 \%$ of those working had obtained A (3.3\%) and A- (7.2\%). 2.1\% of the employed total had grades in the low proficiency range (C+, C and C-) (Table 6). Again, as in 2015 and 2016, the highest unemployed percentage at a combined $31.4 \%$ were among graduates with $\mathrm{B}+$ $(15.7 \%)$ and B (15.7\%) English Language achievements. 9\% of the unemployed graduate total were from the proficient English Language user range with $2.4 \% \mathrm{~A}$ grades and $6.6 \%$ with A-. Only $2.8 \%$ of the unemployed were low proficiency English Language users. 


\section{Statistical Tests for Association between University English Language Results and Graduate Employability in 2015-2017}

Two statistical tests were conducted to determine any relationship between the English Language results of the 2015-2017 batch of these science-based graduates and their overall employability in the job market.

\section{Normality test for University English Language course results}

The Kolmogorov-Smirnov test was applied to test for normality since it was decided that this would be more precise based on the available employability data for the 2015-2017 graduate batch. Normality tests yielding probabilities of $>0.05$ would be indicative that the data was normal whereas probabilities of $<0.05$ would point to the data being not normal. The tests were based on the following hypotheses:

H0: The population is normally distributed.

H1: The population is not normally distributed.

If $\mathrm{p}$-value $<$ significance level $(a=0.05)$, the null hypotheses is rejected.

The normality test results were as follows:

Table 7: Normality test results for 2015 graduate batch

\begin{tabular}{cccrc}
\hline \multirow{2}{*}{2015} & \multirow{2}{*}{$\begin{array}{c}\text { University } \\
\text { English }\end{array}$} & \multicolumn{3}{c}{ Kolmogorov-Smirnova $^{\mathrm{a}}$} \\
\cline { 2 - 5 } & Language Grade & Statistic & df & Sig. \\
\cline { 2 - 5 } Graduate \\
Employability & $\mathrm{A}$ & .346 & 135 & .000 \\
\cline { 2 - 5 } & $\mathrm{A}-$ & .370 & 183 & .000 \\
\cline { 2 - 5 } & $\mathrm{B}$ & .442 & 271 & .000 \\
\cline { 2 - 5 } & $\mathrm{B}-$ & .411 & 135 & .000 \\
\cline { 2 - 5 } & $\mathrm{B}+$ & .396 & 315 & .000 \\
\cline { 2 - 5 } & $\mathrm{C}$ & .356 & .002 \\
\cline { 2 - 5 } & $\mathrm{C}+$ & .462 & 35 & .000 \\
\cline { 2 - 5 } & & &
\end{tabular}

Table 8: Normality test results for $\mathbf{2 0 1 6}$ graduate batch

\begin{tabular}{cccrc}
\hline \multirow{2}{*}{2016} & $\begin{array}{c}\text { University } \\
\text { English }\end{array}$ & \multicolumn{3}{c}{ Kolmogorov-Smirnov $^{\mathrm{a}}$} \\
\cline { 2 - 5 } & $\begin{array}{c}\text { Language Grade } \\
\text { Graduate }\end{array}$ & Statistic & df & Sig. \\
\cline { 2 - 5 } Employability & $\mathrm{A}$ & .376 & 72 & .000 \\
\cline { 2 - 5 } & $\mathrm{A}-$ & .367 & 198 & .000 \\
\cline { 2 - 5 } & $\mathrm{B}$ & .379 & 363 & .000 \\
\cline { 2 - 5 } & $\mathrm{B}-$ & .391 & 196 & .000 \\
\cline { 2 - 5 } & $\mathrm{B}+$ & .352 & 382 & .000 \\
\cline { 2 - 5 } & $\mathrm{C}$ & .403 & 19 & .000 \\
\cline { 2 - 5 } & $\mathrm{C}-$ & .307 & 71 & .000 \\
\hline
\end{tabular}


Table 9: Normality test results for 2017 graduate batch

\begin{tabular}{cccrc}
\hline \multirow{2}{*}{2017} & $\begin{array}{c}\text { University } \\
\text { English }\end{array}$ & \multicolumn{3}{c}{ Kolmogorov-Smirnov $^{\mathrm{a}}$} \\
\cline { 2 - 5 } & Language Grade & Statistic & df & Sig. \\
\cline { 2 - 5 } Graduate & $\mathrm{A}$ & .373 & 87 & .000 \\
\cline { 2 - 5 } & $\mathrm{A}-$ & .393 & 213 & .000 \\
\cline { 2 - 5 } & $\mathrm{B}$ & .404 & 458 & .000 \\
\cline { 2 - 5 } & $\mathrm{B}-$ & .428 & 221 & .000 \\
\cline { 2 - 5 } & $\mathrm{B}+$ & .408 & 484 & .000 \\
\cline { 2 - 5 } & $\mathrm{C}$ & .419 & 15 & .000 \\
\cline { 2 - 5 } & $\mathrm{C}-$ & .385 & 3 & .000 \\
\hline
\end{tabular}

Since the p-value < significance level $(a=0.05)$, the null hypothesis was thus rejected. Due to the normality tests indicating that the population was not normally distributed in 2015, 2016 and 2017, it was decided to proceed with the non-parametric Chi-square test.

\section{Chi-square test for the university English Language course results}

The Chi-square test was applied based on the following hypotheses:

H0: There is no relationship between the university English Language course results and graduate employability.

H1: There is a relationship between the university English Language course results and graduate employability.

The outcomes of the tests were as follows:

Table 10: Chi-square test results for 2015 graduate batch

\begin{tabular}{lccc}
\hline \multicolumn{4}{c}{ Chi-Square Test (2015) } \\
\hline & Value & df & $\begin{array}{c}\text { Asymptotic Significance } \\
(2-\text {-sided })\end{array}$ \\
\hline Pearson Chi-Square & $55.680^{\mathrm{a}}$ & 32 & .006 \\
\hline Likelihood Ratio & 50.033 & 32 & .022 \\
\hline $\mathrm{N}$ of Valid Cases & 1085 & & \\
\hline a. 23 cells (51.1\%) have expected count less than 5. The minimum expected count is .01. \\
\hline
\end{tabular}

Table 11: Chi-square test results for 2016 graduate batch

\begin{tabular}{lccc}
\hline \multicolumn{4}{c}{ Chi-Square Test (2016) } \\
\hline & Value & df & $\begin{array}{c}\text { Asymptotic Significance } \\
\text { (2-sided) }\end{array}$ \\
\hline Pearson Chi-Square & $27.783^{a}$ & 28 & .476 \\
\hline Likelihood Ratio & 27.545 & 28 & .489 \\
\hline N of Valid Cases & 1305 & & \\
\hline a. 14 cells (35.0\%) have expected count less than 5. The minimum expected count is .01. \\
\hline
\end{tabular}


Table 12: Chi-square test results for 2017 graduate batch

\begin{tabular}{|c|c|c|c|}
\hline \multicolumn{4}{|c|}{ Chi-Square Test (2017) } \\
\hline & Value & $\mathrm{df}$ & $\begin{array}{c}\text { Asymptotic } \\
\text { Significance (2- } \\
\text { sided) }\end{array}$ \\
\hline Pearson Chi-Square & $34.677^{a}$ & 35 & .484 \\
\hline Likelihood Ratio & 35.986 & 35 & .422 \\
\hline $\mathrm{N}$ of Valid Cases & 1538 & & \\
\hline
\end{tabular}

Since the p-values for 2015 were smaller than the stated significance level ( $a=$ $0.05)$, the null hypotheses were therefore rejected. On this basis, there was then sufficient evidence to suggest an association between the university English results and graduate employability. However, although it could be surmised that there was an association between the university English Language results and graduate employability in 2015, this could not be conclusively proven for the graduate batch of 2016 and 2017 since there were not enough evidence to indicate this association between the variables.

\subsection{Employment Status and Malaysian University Entrance Test (MUET) Results}

The Malaysian University Entrance Test (MUET) is a pre-requisite entry requirement for any student aiming to enrol in first degree programmes in local Malaysian public or private universities. The test is usually made available to students who are in their final year of secondary school, matriculation programme, diploma-level study or pre-university courses. Results are classified into six bands with Band 1 being the lowest and Band 6 the highest achievement. In the context of the university's first year undergraduates, a student's MUET band classification would determine whether he or she is enrolled into proficiency level English Language classes or into advanced level types. Under the Common European Framework of Reference for Languages (CEFR) proficiency band, MUET Bands 1 and 2 are equivalent to A1 and A2, MUET Bands 3 and 4 to B1 and $\mathrm{B} 2$, and MUET Bands 5 and 6 to $\mathrm{C} 1$ and $\mathrm{C} 2$ respectively.

For the period between 2015-2017, students graduating from the five sciencebased faculties in the university had MUET achievement results across all bands except Band 6 where zero percentage $(0 \%)$ of achievers was recorded. The highest number of graduates who eventually went on to secure job placements were those with MUET Band 3 results (25.5\% in 2015, 26.2\% in 2016, and $22.7 \%$ in 2017). This is followed by Band 4 achievers with 14.4\% in 2015 and 14.1\% in 2016. In 2017, Band 2 achievers recorded the second highest number of employed graduates with $13.5 \%$ (Table 13). 
Table 13: Employability and MUET grades of science-based graduates in 2015, 2016 \& 2017

\begin{tabular}{|c|c|c|c|c|c|c|}
\hline \multirow{2}{*}{$\begin{array}{c}\begin{array}{c}\text { Graduate } \\
\text { Employability }\end{array} \\
\text { MUET } \\
\end{array}$} & \multicolumn{2}{|c|}{$2015(\%)$} & \multicolumn{2}{|c|}{$2016(\%)$} & \multicolumn{2}{|c|}{$2017(\%)$} \\
\hline & Employ. & UnEmploy. & Employ. & UnEmploy. & Employ. & UnEmploy. \\
\hline Band 1 & 0.1 & 0.2 & 0.8 & 0.7 & 1.4 & 1.2 \\
\hline Band 2 & 5.1 & 9.1 & 9.8 & 10.9 & 13.5 & 16.8 \\
\hline Band 3 & 25.5 & 28.4 & 26.2 & 24.2 & 22.7 & 25.4 \\
\hline Band 4 & 14.4 & 15.5 & 14.1 & 11.6 & 11.0 & 7.1 \\
\hline Band 5 & 0.8 & 0.9 & 0.9 & 0.8 & 0.7 & 0.3 \\
\hline Band 6 & 0.0 & 0.0 & 0.0 & 0.0 & 0.0 & 0.0 \\
\hline
\end{tabular}

However, this Band 3 scenario of graduates in gainful employment is replicated in terms of graduates without jobs in 2015, 2016 and 2017. All three years recorded Band 3 achievers as the highest group which was unemployed with $28.4 \%$ in 2015, $24.2 \%$ in 2016 and $25.4 \%$ in 2017. In 2015, the second highest percentage of unemployed graduates were Band 4 achievers at 15.5\%. In 2016, Band 4 again was the second highest with $11.6 \%$ unemployed. In 2017 however, Band 2 came second place in the highest number of unemployed graduates with $16.8 \%$ without any job placements. A very small percentage of graduates in Band 1 were either employed or remained unemployed in 2015 ( $0.1 \%$ and $0.2 \%$ respectively), $2016(0.8 \%$ and $0.7 \%$ respectively) and 2017 (1.4\% and 1.2\% respectively). In fact, the lowest incidence of both employed and unemployed percentage for 2015 and 2016 were among MUET Band 1 graduates. In 2017, the lowest employed-unemployed rate occurred in the Band 5 category with $0.7 \%$ and $0.3 \%$ respectively.

In 2017, the category "Others" was re-defined to include those who were pursuing further qualifications, engaged in further training or acquisition of skills, or waiting for job placements. As such, these groups were deemed as not being technically unemployed in the sense that they were otherwise focusing on other ventures as opposed to being out of work altogether. This inclusion or reclassification could have had influenced the overall employed-unemployed statistics for 2017.

\section{Normality test of graduates' MUET results}

Normality test for the 2015-2017 graduates' MUET results were conducted using the Kolmogorov-Smirnov statistical tests. The hypotheses testing was based on the assumption that:

H0: The population is normally distributed.

H1: The population is not normally distributed.

Tests for normality which yield the p-value $<$ significance level $(a=0.05)$ would render the hypotheses as null. The normality tests results were as follows: 
Table 14: Normality test results of graduates' MUET results in 2015

\begin{tabular}{cccc}
\hline \multirow{2}{*}{2015} & & \multicolumn{2}{c}{ Kolmogorov-Smirnov $^{\mathrm{b}}$} \\
Statistic & df Sig. \\
\hline Graduate & MUET & .385 & 3 \\
\cline { 2 - 4 } & Band 1 & .434 & 154.000 \\
\cline { 2 - 4 } & Band 2 & .401 & 584.000 \\
\cline { 2 - 4 } & Band 3 & .386 & 324.000 \\
\cline { 2 - 4 } & Band 4 & .430 & 19.000 \\
\cline { 2 - 4 }
\end{tabular}

Table 15: Normality test results of graduates' MUET results in 2016

\begin{tabular}{cccr}
\hline \multirow{2}{*}{2016} & MUET & \multicolumn{2}{c}{ Kolmogorov-Smirnov $^{\mathrm{a}}$} \\
Statistic & df Sig. \\
\hline Graduate & Band 1 & .403 & 19.000 \\
\cline { 2 - 4 } Employability & Band 2 & .398 & 270.000 \\
\cline { 2 - 4 } & Band 3 & .373 & 658.000 \\
\cline { 2 - 4 } & Band 4 & .348 & 335.000 \\
\cline { 2 - 4 } & Band 5 & .370 & 23.000 \\
\cline { 2 - 4 } & & &
\end{tabular}

Table 16: Normality test results of graduates' MUET results in 2017

\begin{tabular}{cccr}
\hline \multirow{3}{*}{2017} & & \multicolumn{2}{c}{ Kolmogorov-Smirnova $^{\mathrm{a}}$} \\
& MUET & Statistic & df Sig. \\
\hline Graduate & Band 1 & .403 & 40.000 \\
\cline { 2 - 4 } Employability & Band 2 & .426 & 466.000 \\
\cline { 2 - 4 } & Band 3 & .414 & 739.000 \\
\cline { 2 - 4 } & Band 4 & .359 & 278.000 \\
\cline { 2 - 4 } & Band 5 & .350 & 15.000 \\
\cline { 2 - 4 }
\end{tabular}

The p-value was indicated as < significance level $(a=0.05)$ hence the null hypothesis was rejected. Since the normality test results indicated that the population was all not normally distributed in 2015, 2016 and 2017, the nonparametric Chi-square test was thus conducted.

\section{Chi-square test for MUET test results}

The Chi-square test was conducted based on the following hypotheses:

H0: There is no relationship between MUET test results and graduate employability.

H1: There is a relationship between MUET test results and graduate employability.

The outcomes of the Chi-square tests were as follows: 
Table 17: Chi-square test results for 2015 graduate batch

\begin{tabular}{lccc}
\hline \multicolumn{4}{c}{ Chi-Square Test (2015) } \\
\hline & Value & df & Asymptotic Significance (2-sided) \\
\hline Pearson Chi-Square & $35.913^{\mathrm{a}}$ & 20 & .016 \\
\hline Likelihood Ratio & 30.713 & 20 & .059 \\
\hline N of Valid Cases & 1085 & & \\
\hline a. 15 cells (50.0\%) have expected count less than 5. The minimum expected count is .01. \\
\hline
\end{tabular}

Table 18: Chi-square test results for 2016 graduate batch

\begin{tabular}{lccc}
\hline \multicolumn{4}{c}{ Chi-Square Test (2016) } \\
\hline & Value & df & Asymptotic Significance (2-sided) \\
\hline Pearson Chi-Square & $22.370^{\mathrm{a}}$ & 16 & .132 \\
\hline Likelihood Ratio & 24.870 & 16 & .072 \\
\hline N of Valid Cases & 1305 & & \\
\hline a. 9 cells (36.0\%) have expected count less than 5. The minimum expected count is .06. \\
\hline
\end{tabular}

Table 19: Chi-square test results for 2017 graduate batch

\begin{tabular}{|c|c|c|c|}
\hline \multicolumn{4}{|c|}{ Chi-Square Test (2017) } \\
\hline & Value & $\mathrm{df}$ & Asymptotic Significance (2-sided) \\
\hline Pearson Chi-Square & $45.422^{\mathrm{a}}$ & 20 & .001 \\
\hline Likelihood Ratio & 43.099 & 20 & .002 \\
\hline $\mathrm{N}$ of Valid Cases & 1538 & & \\
\hline a. $\quad 8$ cells $(26.7 \%)$ & xpected & 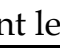 & 5. The minimum expected count \\
\hline
\end{tabular}

Since the p-values in 2015 and 2017 (Table 17 \& Table 19) were smaller than the chosen significance level $(a=0.05)$, the null hypotheses were thus rejected. Although there is evidence to suggest a link between MUET test results and graduate employability, this assumption is limited to 2015 and 2017 since no association between the variables could be conclusively proven for 2016 (Table 18).

\section{Discussion}

Although the numerical figure of unemployed graduates seemed to be on the increase every year compared to those with job placements, in actuality there was a gradual decrease in terms of percentage in 2015, 2016 and 2017. When the normality tests performed found the population as not normally distributed, nonparametric Chi-square tests were conducted to test for association between the variables. While the Chi-square test results highlighted sufficient evidence to suggest an association between graduate employability and the university English Language course results in 2015, this assumption however could not be applied for the 2016 and 2017 batches since the results were inconclusive, that is, not enough evidence was presented to support such an association. The Chisquare tests conducted to ascertain links between MUET test results and graduate employability similarly showed sufficient evidence to suggest an association for 
the 2015 and 2017 graduates but this too could only be applied with caution since for 2016 no such association was highlighted.

Based on these, an assumption that might be drawn is that for the university's science-based graduates of 2015, 2016 and 2017, their English Language proficiency was not a major denominator in their level of employability. This likelihood is evidenced by the findings where an almost equal number of employed and unemployed graduates were found to be mostly from the $\mathrm{B}+$ and $B$ achievement range in their English Language courses in the university. In terms of MUET results, the highest number of unemployed graduates were from Band 3 followed close behind by Band 4 achievers. While Band 3 achievers could be viewed as relatively able users of the English language, attainment of Band 4 denotes the user as sufficiently proficient in the language. A summary of the employment status of these proficient users of English is presented in Table 20.

Table 20: Percentage of proficient users of English for the graduating class of 2015, 2016 and 2017

\begin{tabular}{ccccccc}
\hline & \multicolumn{2}{c}{2015} & \multicolumn{2}{c}{2016} & \multicolumn{2}{c}{2017} \\
\cline { 2 - 6 } & Empl & UnEmpl & Empl & UnEmpl & Empl & UnEmpl \\
\hline $\begin{array}{c}\text { MUET } \\
\text { Bands } \\
4 \text { \& 5 }\end{array}$ & $15.2 \%$ & $16.4 \%$ & $15.0 \%$ & $12.4 \%$ & $16.7 \%$ & $7.4 \%$ \\
\hline $\begin{array}{c}\text { University } \\
\text { results } \\
\text { A \& A- }\end{array}$ & $16.0 \%$ & $13.4 \%$ & $10.8 \%$ & $9.9 \%$ & $10.5 \%$ & $9.0 \%$ \\
\hline
\end{tabular}

From Table 20, it could be surmised that the level of English language competence, although providing an advantage for graduates, was not the main criteria for securing jobs since an almost similar percentage of these MUET band achievers and university English Language top graders were without employment.

\subsection{Employability Value}

The findings of this study point to several pertinent highlights on the issue of employability value of university graduates as a whole. Among these is the factor of area of specialisation or field of study undertaken at university as a primary indicator of future job prospects. Graduates from the Faculty of Food Science and Nutrition programmes were found to be the most employable among all the five university's science-based faculties with 56.3\% (2015), 61.8\% (2016) and 59.2\% (2017) in full-time jobs in various sectors. Data on their job locations and area of workplace responsibilities however could not be obtained since these were considered confidential although it could be deduced that Malaysia's status as an emerging hub for small and medium enterprises (SMEs) could be a contributing factor to the availability of jobs in this particular sector.

There is also a possibility that for industry-based jobs, absolute language accuracy may not be an absolute pre-requisite; fluency and the ability to convey information and be understood might be more sufficient. This is in comparison to jobs that require day-to-day interaction with clients and the public (such as in the 
service industry) where understanding, business success and clientele goodwill are tied to accurate exchange and conveying of message and intent. This scenario could explain the preponderance of employed graduates being MUET Band 3 users and university B+ and B scorers from these five science-based faculties.

\subsection{Graduate Mobility}

Again, absence of concrete data on the job placement locations of the university's graduates for 2015, 2016 and 2016 limits the presentation of a more accurate description of the employability factors at play. An assumption that could be made related to the employability of young graduates is the notion of mobility or willingness to relocate to wherever jobs might be available. Sabah is located in the Malaysian area of Borneo Island, sharing the territory together with Malaysian state of Sarawak, Brunei Darussalam, and the Indonesian region of Kalimantan. Sabah is accessible by land or air with flights from Kuala Lumpur, Singapore and Manila approximately 2.5 hours in duration. Although jobs in this region may be available, the range and scope of specific occupations or roles is limited due in part to different (or lack of) stages of development compared to other locations in Malaysia, distance from the national capital, level of investment or funding to drive industry and technical development, availability and access of infrastructure and facilities, and scarcity of support and expertise, and air and sea transportation costs, among other things. These, combined together, create a less than vigorous condition for jobs to be created or sustained, especially work that is expertise-specific or expertise-oriented. Many of this type of work environment would be available in localities elsewhere where the infrastructure and human expertise or capital is already established and the eco-system supportive, for example, in Kuala Lumpur, Penang, Johor or Singapore. Lack of relevant job opportunities creates a scenario whereby for young graduates, securing a job directly related to their field of study or specialisation might in most instances require them to relocate or uproot to these cities or industrial enclaves. The majority of the students in this university are local Sabahans, and the need for mobility would inadvertently impact their decision to whether to get a job but move out of the state, or stay home in Sabah and remain jobless (or stay and work in an area not related to one's degree or training). This mobility aspect is perhaps a critical variable that could be investigated in future graduate employability studies.

\subsection{Attitude and Transversal Skills}

Transversal or soft skills is another employability attribute that provides graduates with strong added value when seeking employment. Transversal knowledge, skills and competencies form the 'building blocks' for the development of hard skills and competencies required to succeed in the labour market. Comparable to $21^{\text {st }}$ century skills, transversal skills could be learnt attributes: an ideal university study curriculum would be one that focuses and hones on these aspects of an individual's personality. In the case of the employed science-based graduates who had obtained mid-range results in their MUET and university English Language courses, perhaps their ability to engage or demonstrate their thinking or hands-on skills during their job interviews provided them with an edge over their more English language conversant competitors. Therefore, in as much as an individual's English language 
proficiency could put him at an advantage during job interviews, the job in all probability would be for those who are able to respond critically, creatively and rapidly to solution-based workplace issues or scenarios put forward by prospective employers to test the thinking and reasoning skills of their potential workers.

A critical implication here therefore is this: universities would do well to integrate transversal skills learning or acquisition in their curriculum, and in so doing equip their graduates when they enter the labour market with the on-the-job ability to problem-solve or address work issues accordingly. Although a study by Nazron, Lim and Nga (2017) suggested a tenuous relationship at best between the employment status of graduates and their soft skills, current rapid advancement in technology and the shift to more online-based interaction between client and provider in the post COVID-19 era where business decisions would likely be based equally on what is known and what is assumed require workers who are knowledgeable, skilful and able to think on their feet and out-of-the-box.

\subsection{Workplace Environment Readiness and Resilience}

If transversal skills could be viewed as a platform from which new graduates could attune to required job conditions, workplace readiness would be the state of preparedness or adaptability of the workers as they enter into any organisation. Workplace entities are structured along very defined frameworks of organisational culture, values and expectations (Hardin-Ramanan, Gopee, Rowtho, \& Charoux, 2020) and prospective employers would be searching for potential employers who exhibit attributes that complement their established work culture. Graduates are viewed as "complete" products in terms of their qualifications, but this theory-based knowledge has to be supported by the employee's willingness to learn on-the-job and respond to the demands and challenges of the organisation pertaining to aspects such as to working hours, salary, and benefits. As reiterated by Zakaria, Yusoff, Ibrahim and Tibok (2020), there is a real need to establish cohesive cooperation and collaboration frameworks between industry and institutions of higher learning as such networks would certainly help provide job exposure and working life insights while at the same time build their work-related social network (Yong, 2017), promote employment opportunities and improve undergraduates' opportunities of joining these organisations at a later stage. In this respect, universities have a critical role in ensuring that these elements of graduate capital-building are integrated within their curriculum and what is taught in the lecture halls fit into the needs and expectations of industry as the end-receiver of the human capital products.

\section{Conclusion}

In the context of graduate employability in Malaysia, proficiency in the English language is often highlighted as a main determinant in how employable the graduate is. This study however has not ascertained any concrete relationship between science graduates' employability and their level of English language proficiency with the link, at the most, tenuous. The evidence instead suggests the interplay of other factors such as geographical location, economic rigour of the 
region, matching of university study programmes to local job markets, individual resilience, and graduate mobility (willingness to go where work is available) as critical attributes in the discourse on graduate employability. It is therefore imperative that any future curriculum review or new programme initiative take into consideration these factors to ensure that a more appropriate or responsive learning ecosystem could be conceptualised.

\section{Acknowledgement}

This research was supported by Universiti Malaysia Sabah under Grant Award No. SDK0060-2018.

\section{References}

Ahmad, N. A., Kenayathulla, H. B., \& Idris, A. R. (2017). Employability skills for hospitality students in Malaysia. Malaysian Online Journal of Educational Management, 5(4), 63-86.

Alias, R., Hamzah, M. I. M., \& Yahya, N. (2013). Generic skill requirements: Between employer's aspiration and the need of professional employees. Jurnal Pengurusan, 37, 105-114.

D'Silva, V. (2020). More and more graduates are facing unemployment in Malaysia. New Straits Times. https://www.nst.com.my/news/nation/2020/02/562309/moreand-more-graduates-are-facing-unemployment-malaysia

Field, A. (2009). Discovering Statistics Using SPSS Third Edition. SAGE.

Ghasemi, A., \& Zahediasl, S. (2012). Normality tests for statistical analysis: A guide for non-statisticians. International Journal of Endocrinology and Metabolism, 10(2), 486-489. https://doi.org/10.5812/ijem.3505

Hadiyanto \& Ibrahim, M. S. B. (2013). Students' generic skills at the National University of Malaysia and the National University of Indonesia. Procedia - Social and Behavioral Sciences, 83, 71-82. https://doi.org/10.1016/j.sbspro.2013.06.015

Hamid, M. S. A., Islam, R., \& Abd Manaf, N. H. (2014). Employability skills development approaches: An application of the analytic network process. Asian Academy of Management Journal, 19(1), 93-111.

Hanapi, Z., \& Nordin, M. S. (2014). Unemployment among Malaysia graduates: Graduates' attributes, lecturers' competency and quality of education. Procedia Social and Behavioral Sciences, 112, 1056-1063. https://doi.org/10.1016/j.sbspro.2014.01.1269

Hardin-Ramanan, S., Gopee, S., Rowtho, V., \& Charoux, O. (2020). Graduate workreadiness in Mauritius: A multi-stakeholder approach. Journal of Teaching and Learning for Graduate Employability, 11(1), 93-109.

Ilhaamie, A. G. A., Rosmawani, C. H., \& Yusmini, M. Y. (2018). The employability skills of Malaysian university students. International Journal of Modern Trends in Social Sciences, 1(3), 1-14.

Koo, Y. L. (2007). Mindful PluriLiteracy (PL) for multilingual learners: Sustaining diverse cultures in language and literacy education. In A. Pandian, Y. L. Koo \& P. Kell. (Eds). Innovation and intervention in ELT: Pathways and practices. (pp. 201-223) Universiti Putra Malaysia Press.

Lee, T. H., Ling, C. C., Lim, Y. M., \& Cham, T. H. (2019). University education and employment challenges: An evaluation of fresh accounting graduates in Malaysia. International Journal of Academic Research in Business and Social Sciences, 9(9), 10611076. 
Ministry of Education. (2015). Malaysia Education Blueprint 2015-2025 (Higher Education). Kementerian Pendidikan Malaysia.

Ministry of Higher Education. (2007) The National Higher Education Action Plan (20072010). Kementerian Pengajian Tinggi Malaysia.

Murugasu, A., Hakim, M. I., \& Yau, Y. S. (2019). Are Malaysian workers paid fairly? An assessment of productivity and equity. BNM Annual Report 2018, 35-47.

Nazron, M. A., Lim, B., \& Nga, J. L. (2017). Soft skills attributes and graduate employability: A case in Universiti Malaysia Sabah. Malaysian Journal of Business and Economics, 4(2), 65-76. https://jurcon.ums.edu.my/ojums/index.php/mjbe/article/view/1080/709

Omar, N. H., Manaf, A. A., Mohd, R. H., Kassim, A. C., \& Abd Aziz, K. (2012). Graduates' employability skills based on current job demand through electronic advertisement. Asian Social Science, 8(9), 103-110.

Rasul, M. S., Rauf, R. A. A., Mansor, A. N., Yasin, R. M., \& Mahamod, Z. (2013). Graduate employability for manufacturing industry. Procedia - Social and Behavioral Sciences, 102, 242-250. https://doi.org/10.1016/j.sbspro.2013.10.739

Singh, P., Thambusamy, R. X., \& Ramly, A. (2016). Assessing graduates' generic skills: An indicator of employability. Pertanika Journal of Social Sciences \& Humanities, 22(3), 845-860.

Turner, R. (2004). Towards a structural model connecting hard skills, soft skills and job conditions and the IS professional: The student perspective. Issues in Informing Science and Information Technology, 4, 977-991. https://doi.org/10.28945/2782

Wong, S. P., Samsilah, R., Siaw, Y. L, Tajularipin, S., \& Habibah, A. B. (2018). The employability of undergraduate students in a Malaysian higher educational institution. Educational Leader, 6, 165-182.

Wuensch, K. L. (2011). Chi-Square Tests. International Encyclopedia of Statistical Science, 252-253. https://doi.org/10.1007/978-3-642-04898-2_173

Yahaya, A. S., Ahmed, A., Gabda, D., \& Na, C. S. (2008). Problem and solution in statistics for engineers and scientists. Prentice Hall.

Yong, C. (2017). Graduate employability: The perspective of social network learning. Eurasia Journal of Mathematics, Science and Technology Education, 13(6), 2567-2580. https://doi.org/10.12973/eurasia.2017.01241a

Yorke, M. (2006). Employability in higher education: What it is - What it is not. The Higher Education Academy.

Yusof, N., \& Jamaluddin, Z. (2015). Graduate employability and preparedness: A case study of University of Malaysia Perlis (UNIMAP), Malaysia. Geografia Malaysian Journal of Society and Space, 11(11), 129-143.

Zainuddin, S. Z., Pillai, S., Dumanig, F. P., \& Phillip, A. (2019). English language and graduate employability. Education + Training, 61(1), 79-93. https://doi.org/10.1108/ET-06-2017-0089

Zakaria, N. S., Yusoff, K. Y. S. K. M., Ibrahim, D., \& Tibok, R. P. (2020). Career after graduation: Future graduates' perceptions of job attributes in small and medium enterprises (SMEs) and multi-national corporations (MNCs). e-Bangi, 17(6), 252-264. 